\title{
О концепции развития нормативно-технической базы строительных объектов в период их эксплуатации
}

\author{
В.И.Травуш, Горпроект, РААСН, Москва \\ В.В.Гурьев, ФАУ «ФЦС», Москва \\ А.Н.Дмитриев, РЭУ, Москва \\ В.М.Дорофеев, ФАУ «ФЦС», Москва \\ Ю.С.Волков, НИИЖБ им. А.А.Гвоздева, Москва
}

Рассмотрены проблемы недостаточного развития в России нормативно-технической документации по стадиям жизненного цикла объекта капитального строительства в свете требований Технического регламента о безопасности зданий и сооружений, утверждённого Федеральным законом № 384. Проведён анализ действующих в этой сфере нормативных документов и показан дефицит норм для эксплуатационной стадии, стадии демонтажа и нормативных сроков эксплуатации и их отсутствие для стадии утилизации, оценки состояния, долговечности. Выполнен обзор и анализ аварий различных видов строительных объектов в России и за рубежом, который подтвердил необходимость совершенствования и развития нормативной базы в области механической безопасности на протяжении жизненного цикла зданий. Приведены сведения по объёму и составу существующего жилого фонда России с разбивкой на работоспособное, аварийное и ветхое жилье, видам конструктивных систем, по годам - с 2010-го по 2018-ый год. На основе результатов обследования массовых серий первого периода индустриального крупнопанельного домостроения в Москве даны рекомендации для принятия решений по их модернизации. Основное внимание уделено требованиям новых базовых сводов правил в области механической безопасности и требованиям экологичности и энергоэффектиности зданий при эксплуатации. Рассмотрен опыт создания зарубежных и отечественных нормативов для цифрового моделирования эксплуатации, включая использование цифровых моделей объектов. Даны предложения по концепции развития нормативной базы на основе обеспечения комплексной безопасности объектов на протяжении их полного жизненного цикла с выделением первоочередных работ.

Ключевые слова: строительные объекты, эксплуатация, нормирование, анализ, концепция развития, комплексная безопасность, первоочередные научно-исследовательские работы.

On the Concept of Development of the Regulatory and Technical Base of Construction Objects during their Operation

V.I.Travush, Gorproekt, RAACS, Moscow

V.V.Guryev, FCS, Moscow

A.N.Dmitriev, REA, Moscow

V.M.Dorofeev, FCS, Moscow

Yu.S.Volkov, NIIZHB named after Gvozdev, Moscow
The problems of insufficient development of normative and technical documentation on the stages of thelife cycle of the capital construction object in thelight of the requirements of the Technical Regulations on the Safety of Buildings and Structures are considered. The analysis of the existing documents is carried out and the deficit of standards on the operational stage and especially on the stage of utilization is shown. Information is provided on the volume and composition of the existing housing stock, broken down into functional, emergency, and dilapidated housing types of structural systems, analysis of accidents of various types. The main attention is paid to the requirements of the new basic codes of rules in the field of mechanical, environmental safety, and energy efficiency of buildings during operation. The experience of creating foreign and domestic standards for digital modeling of operation, including the use of digital models of objects, is considered. Proposals are given for the concept of development of the regulatory framework based on ensuring the comprehensive safety of objects during their full life cycle with the allocation of priority works.

Keywords: regulatory and technical documentation, technical regulation, operational safety, object life cycle, workable categories, digital modeling.

Надёжность зданий и сооружений являются основным фактором обеспечения безопасности среды обитания. Формируемая через строительную деятельность, среда обитания человека является синтезом социальных, экологических и экономических акций и регулируется применением Федерального закона «Технический регламент «0 безопасности зданий и сооружений» [14]. Безопасность среды обитания является слагаемым многих факторов, начиная от квалификации проектировщика и качества проектирования, выполнения требований норм и стандартов, обеспечения качества производства работ и т.д.

Практически всю свою жизнь (не менее 90\% времени) человек проводит в искусственной среде обитания, то есть внутри помещений или вблизи зданий различного назначения, что, безусловно, накладывает отпечаток на его психику, определяет его восприятие окружающей действительности. Таким образом, основные жизненные приоритеты личности - среда обитания, безопасность жилища и многое другое, обеспечивается через строительную деятельность. 
Объём мирового строительства ежегодно превышает 4 трлн долларов, что выше общемировых затрат на многие другие виды человеческой деятельности, в том числе и на военные цели, поэтому прогресс в строительном секторе во всех развитых странах, и Россия не исключение, в значительной мере определяет состояние всей национальной экономики. Успех решения текущих и отдалённых задач, стоящих перед человеческим сообществом, напрямую зависит от строительного сектора экономики.

В России на построенные здания и сооружения в стоимостном выражении приходится $60 \%$ национального достояния страны. На их теплозащиту и коммунальное обслуживание расходуется более $60 \%$ вырабатываемой в стране энергии.

Время жизни отдельных строительных объектов часто достигает столетий, и для экономической эффективности обеспечения их безопасности в период эксплуатации требуются комплексные решения на различных стадиях их жизненных циклов. После выхода в 2009 году Технического регламента о безопасности зданий и сооружений [14] и пересмотра и актуализации нормативной базы проектирования в строительстве остро встаёт вопрос о развитии нормативных документов в части эксплуатационной и ликвидационной стадий объектов. Особенно он становится актуальным в рамках реализации национального проекта «Жильё и городская среда», в котором поставлена задача сноса ветхого и аварийного жилья [1]. Предотвратить резкий и «неожиданный», как сегодня, переход существующего капитального жилого фонда в ветхий, а тем более аварийный фонд, - серьёзная проблема для науки и проектирования и здесь без проведения комплекса исследований и совершенствования нормативной базы не обойтись. С другой стороны, одной только механической и пожарной безопасностью этой проблемы не решить.

Как известно, Технический регламент о безопасности зданий и сооружений [14] устанавливает минимально необходимые требования к зданиям и сооружениям (в том числе к входящим в их состав сетям и системам инженерно-технического обеспечения), а также к связанным со зданиями и с сооружениями процессам проектирования (включая изыскания), строительства, монтажа, наладки, эксплуатации и утилизации (сноса), в том числе требования:

1) механической безопасности;

2) пожарной безопасности;

3) безопасности при опасных природных процессах и явлениях и (или) техногенных воздействиях;

4) безопасных для здоровья человека условий проживания и пребывания в зданиях и сооружениях;

5) безопасности для пользователей зданиями и coopyжениями;

6) доступности зданий и сооружений для инвалидов и других групп населения с ограниченными возможностями передвижения;

7) энергетической эффективности зданий и сооружений;

8) безопасного уровня воздействия зданий и сооружений на окружающую среду.
Все эти направления относятся и к процессу эксплуатации, поэтому по всем этим направлениям необходима своя система нормативно-технических документов, обеспечивающих выполнение требований [14]. При этом следует иметь в виду, что безопасная эксплуатация конкретного объекта обосновывается его функциональным назначением.

Из перечисленных направлений безопасности следует обязательно отметить также энергоэффективность и экологическую безопасность, поскольку они тесно связаны с эксплуатационной и ликвидационной фазами жизненного цикла, его экономикой и должны сопровождаться соответствующими нормативами. На этих стадиях для обеспечения необходимой безопасности строительного объекта при минимальной совокупной его стоимости часто целесообразно (при достаточной обоснованности) увеличение первоначальных затрат на стадии проектирования и строительства на применение энергоэффективных, экологичных технологий и подходов «зелёного» строительства и стандартов экологического соответствия [2], в результате чего на стадии эксплуатации здания существенно сокращаются расходы на его безопасное содержание, составляющие в среднем 75\% от общих затрат (рис. 1).

Это необходимо делать уже на начальном этапе жизненного цикла - при инициации проекта, в процессе формирования цифровой модели и при выборе принципиальных проектных решений на предпроектной стадии (обоснования инвестиций), и более детально - в процессе проектирования: по мере поиска и сравнения альтернативных решений для выбора наиболее эффективного варианта. Общая стоимость обеспечения безопасности строительных объектов на жизненном цикле, но уже в застройке - третья сторона вопроса, и она в значительной мере зависит от конкретных условий и требований участка строительства: учёта требований устойчивого развития территорий, на которых осуществляется строительство; климатических, геологических, гидрофизическиххарактеристик района (сейсмические, вечномёрзлые, подтопляемые грунты и др.), наличия и близости мощностей для производства конструкций, материалов и сырья, окружающей инфраструктуры; обеспечения комплексности и антитеррористической защищённости застройки; эффективности использования материальных и трудовых ресурсов и др.

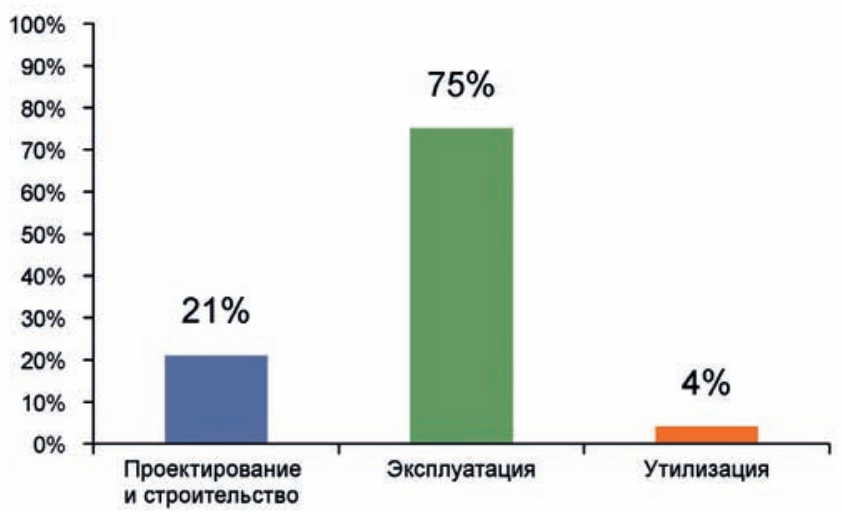

Pис. 1. Усреднённые затраты на протяжении жизненного цикла здания. Схема авторов статьи 
В этом отношении тоже необходимы соответствующие исследования, методики и стандарты, аналогичные проведённым в работе [3]. Что касается экологической безопасности, требования к которой пока содержатся в добровольной части стандартов и в «зелёном» ГОСТ Р 54964-2012 [15], то пока, например, важнейших для эксплуатации и ликвидации объекта норм по обеспечению ремонтопригодности и утилизации зданий нет.

Необходимы единая структура стандартов жизненного цикла зданий и сооружений (от инженерных изысканий до вывода объектов из эксплуатации, в том числе единые стандарты строительного комплекса в сферах выполнения инженерных изысканий, архитектурно-строительного проектирования, строительства и реконструкции, эксплуатации и утилизации объектов капитального строительства), а также проведение контроля за их соблюдением.

До 2003 года в РФ существовала структура нормативных документов, которая была представлена в СНиП 10-01-94 «Система нормативных документов в строительстве. Основные положения», в соответствии с которой в стране в области строительства действовали различные нормативно-технические документы.

В 2003 году вышел Федеральный закон «0 техническом регулировании» [16], согласно которому установлена другая номенклатура нормативно-технической документации, при этом отсутствует документ, структурирующий всю систему строительных норм, подобно ранее действующему СНиП 10-01-94, а также не предусмотрено и специальных нормативов по эксплуатации, реконструкции и ликвидации зданий и сооружений.

В настоящее время в строительной отрасли РФ согласно «Реестру документов в области инженерных изысканий, проектирования, строительства и сноса», утверждённому Постановлением Правительства Российской Федерации № 1417 от 12.09.2020 г. (далее - Реестр) разработано и актуализировано более 300 Сводов правил - СП, и свыше 1000 национальных и межгосударственных стандартов ГОСТ Р и ГОСТ, но в техническом регулировании строительства до настоящего времени не решён ряд проблем. Одна из них - противоречивость обязательности и добровольности применения нормативов в проектной и производственной практике.

Утверждённый 4 июля 2020 года Постановлением Правительства № 985 Перечень нормативных документов обязательного применения, как и предыдущий, содержит концептуальные ошибки, когда нормативный документ делится на части для добровольного и обязательного применения.

Перечень содержит всего 78 документов, из них четыре ГОСТа и 74 свода правил - СП. Кроме указанного Перечня, Федеральным агентством по техническому регулированию и метрологии приказом от 17 апреля 2019 года № 831 утверждён перечень документов в области стандартизации, в результате применения которых обеспечивается соблюдение требований этого же Федерального закона, но на добровольной основе. В этот добровольный перечень вошли 485 документов, в том числе повторены как добровольные все
ГОСТы и СП из обязательного перечня. По данным доклада на Госсовете 17 апреля 2019 года по вопросам развития строительного комплекса Российской Федерации в отрасли действуют 320 сводов правил и более 900 стандартов. Таким образом, вне официальной системы документов обязательного и добровольного применения действуют ещё порядка 800 документов, причём значимых, статус которых официально не определён (некоторым образом - «нелегалов») [4; 5].

Перечень вызывает много вопросов не только в части его краткости, но и по содержанию. Например, в обязательном Перечне указано лишь четыре ГОСТа, но нет стандартов, определяющих правила контроля прочности всех остальных видов стройматериалов. Следует отметить, что стандарты на методы испытаний стройматериалов «бесхозные», их в данный момент нет ни в добровольном ни в обязательном Перечне.

Поэтому авторами в соответствии с этапами жизненного цикла здания и сооружения, определёнными «Техническим регламентом о безопасности зданий и сооружений», предлагается следующая структура нормативно-технической базы в области строительства для обеспечения безопасности зданий и сооружений (рис. 2). Эта структура может быть принята за основу при подготовке новой редакции основополагающего документа (СН, СНиП) «Система нормативных документов в строительстве. Основные положения».

Технический регламент о безопасности зданий и сооружений [14] устанавливает минимально необходимые требования к зданиям и сооружениям (в том числе к входящим в их состав сетям инженерно-технического обеспечения и системам инженерно-технического обеспечения), а также к связанным со зданиями и с сооружениями процессам проектирования (включая изыскания), строительства, монтажа, наладки, эксплуатации и утилизации (сноса). Для этапа «Возведение», согласно Реестру, разработан обширный комплекс нормативных документов, в то время как для этапа «Эксплуатация» разработаны только отдельные документы (24 ед.), не охватывающие всей номенклатуры функциональных элементов строительных объектов и всех стадий этого жизненного цикла. Практически отсутствуют документы, регламентирующие процесс сноса и утилизации зданий и сооружений (1 ед.). Между тем это важная компонента процесса проектирования по жизненному циклу, включающего в себя все этапы существования объекта.

Разработанным согласно этой структуре базовым документом, устанавливающим общие эксплуатационные требования к зданиям и сооружениям в условиях нормальной эксплуатации, в настоящее время является СП 255.1325800.2016 [17]. Этот документ не распространяется на особо опасные, технически сложные и линейные объекты.

В этом нормативном документе приведена классификация зданий (сооружений) по типам эксплуатационных режимов с учётом функционального назначения; эксплуатационные требования к зданиям (сооружениям); состав и содержание раздела проектной документации «Требования к безопасной эксплуатации объекта капитального строительства»; обязан- 


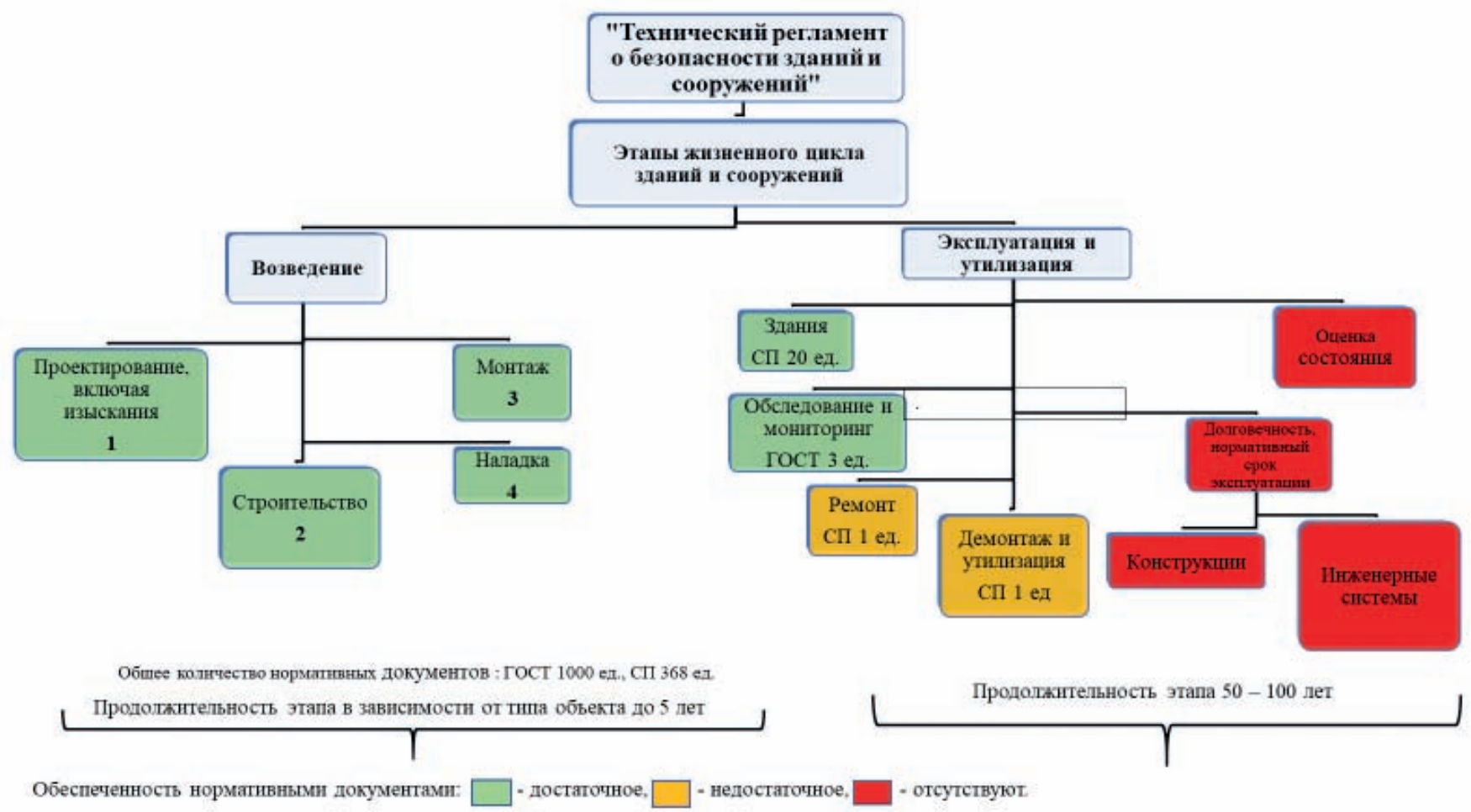

Рис. 2. Структура нормативной базы зданий и сооружений в соответствии с этапами жизненного цикла. Схема авторов статьи

ности службы эксплуатации; организационные основы эксплуатационного контроля; организационные основы технического обслуживания зданий (сооружений); эксплуатация несущих конструкций; эксплуатация ограждающих конструкций; эксплуатация систем инженерно-технического обеспечения; эксплуатация вертикального транспорта; обеспечение пожарной безопасности; обеспечение безопасных для здоровья людей условий проживания и пребывания в зданиях (сооружениях); обеспечение безопасности для пользователей здания (сооружения); выполнение требований доступности зданий (сооружений) для маломобильных групп населения; техническая эксплуатационная документация (состав, ведение и хранение).

Остановимся более подробно на рассмотрении нормативного обеспечения механической безопасности зданий и сооружений в период их эксплуатации.

Под механической безопасностью в соответствии с Техническим регламентом о безопасности зданий и сооружений [14] понимается состояние строительных конструкций и основания здания или сооружения, при котором отсутствует недопустимый риск, связанный с причинением вреда жизни или здоровью граждан, имуществу физических или юридических лиц, государственному или муниципальному имуществу, окружающей среде, жизни и здоровью животных и растений вследствие разрушения или потери устойчивости здания, сооружения или их части. В упомянутом документе, как уже отмечалось, приводятся основные положения по обеспечению механической безопасности зданий и сооружений на всех этапах жизненного цикла строительного объекта.
Исключение недопустимого риска обеспечивается путём применения системы коэффициентов, учитывающих возможные неблагоприятные отклонения значений нагрузок, характеристик материалов и расчётной схемы строительного объекта от реальных условий его эксплуатации, а также уровень ответственности строительных объектов. Вводится четыре типа коэффициентов надёжности: коэффициенты надёжности по нагрузке, коэффициенты надёжности по материалу, коэффициенты условий работы, коэффициенты надёжности по ответственности сооружений и статистической обеспеченности прочностных характеристик строительных материалов.

По данным Минстроя России ${ }^{1}$ только жилой фонд страны в 2018 году составил порядка 2857 млн кв. м. При этом по тем же данным 0,7\% этого фонда является аварийным, то есть не обеспечивается его механическая безопасность. С целью демонстрации динамики и масштаба аварийного жилищного фонда страны в таблице 1 приведена информация за период 2010-2018 годов.

На рисунке 3 представлена информация о структуре многоквартирных домов жилого фонда России, в том числе аварийного [6]. Как видно из рисунка, основной объём аварийного жилья приходится одно-двухэтажные деревянные (59\%) и кирпичные (21\%) здания и только 5\% - на панельные дома. Правила отнесения к аварийным домам определяющим фактором назначают их недостаточную механическую безопасность.

${ }^{1}$ Жилищные условия. Федеральная служба государственной статистики. Официальный сайт (https://rosstat.gov.ru/folder/13706). 
Конструктивные системы наиболее распространённых 9-12-этажных домов типовых серий: II-49Д, II-49П, II-57 - внутренние несущие поперечные железобетонные панели стен и перекрытий с наружными трёхслойными панелями с различными типами утеплителей и однослойными керамзитобетонными панелями; I-515 - внутренние несущие продольные железобетонные панели стен и перекрытий с трёхслойными наружными панелями; II-18, И-209A - внутренние несущие железобетонные панели стен с широким шагом и многопустотные панели перекрытий с наружными стенами из керамзитобетонных блоков.

Тем не менее в последние годы аварии жилых домов (причины обрушения конструкций) часто связывают с низкой пожарной безопасностью. В действительности прогрессирующее обрушение перекрытий при пожаре часто происходит при механическом воздействии взрыва бытового газа (рис. 4).

В Москве была проделана большая работа по обследованию и защите зданий массовых серий от прогрессирующего обрушения, выпущены соответствующие нормативные документы, откорректированы типовые проекты, этот опыт необходимо использовать и в других городах.

Было обследовано более четырёхсот жилых 5-14-этажных типовых домов наиболее распространённых серий и их модификаций $[7 ; 8]$. Конструктивной основой этих зданий являются несущие внутренние железобетонные стены и перекрытия с наружными панелями из керамзитобетона, трёхслойными железобетонными панелями с утеплителем из цементного фибролита или пенопласта, керамзитобетонных блоков и др. Дома обладают достаточным запасом прочности основных несущих конструкций (табл. 2).

Коэффициент использования несущей способности для 9-12-этажных домов наиболее распространённых серий II-18 и II-49 находится в диапазоне $K_{\text {исп }}=0,7-0,5$, то есть в соответствии с [18] эти дома по механическим показателям находятся в «работоспособном техническом состоянии».

По-видимому, хуже обстоят дела с механической безопасностью при эксплуатации не жилых, а большепролётных зданий и сооружений. На рисунке 5 приведены примеры аварий на подобных объектах.

Анализ аварий, проиллюстрированных на последних рисунках, указывает на то, что их причинами были нарушения на различных этапах жизненного цикла этих сооружений, то есть механическая безопасность не обеспечивалась как на стадии проектирования (рис. 5 a, б, г) и строительства (рис. 5 а, в, г) так и на стадии эксплуатации (рис. 5 б, в).

Это указывает на то, что нормативно-техническая база обеспечения механической безопасности строительных объ-

Таблица 1. Изменение объёма аварийного жилищного фонда в период 2010-2018 годов

\begin{tabular}{|c|c|c|c|c|c|c|c|c|c|}
\hline Годы & 2010 & 2011 & 2012 & 2013 & 2014 & 2015 & 2016 & 2017 & 2018 \\
\hline Аварийный жилищный фонд, млн. кв. м & 20,5 & 20,5 & 22,2 & 23,8 & 23,8 & 19,6 & 22,7 & 24,6 & 25,5 \\
\hline $\begin{array}{c}\text { Удельный вес аварийного жилищного фонда в общей } \\
\text { площади всего жилищного фонда, процентов }\end{array}$ & 0,6 & 0,6 & 0,7 & 0,7 & 0,7 & 0,5 & 0,6 & 0,7 & 0,7 \\
\hline
\end{tabular}

Структура и характер технического состояния многоквартирных домов жилищного фонда г.

Москвы на 1.01.2006
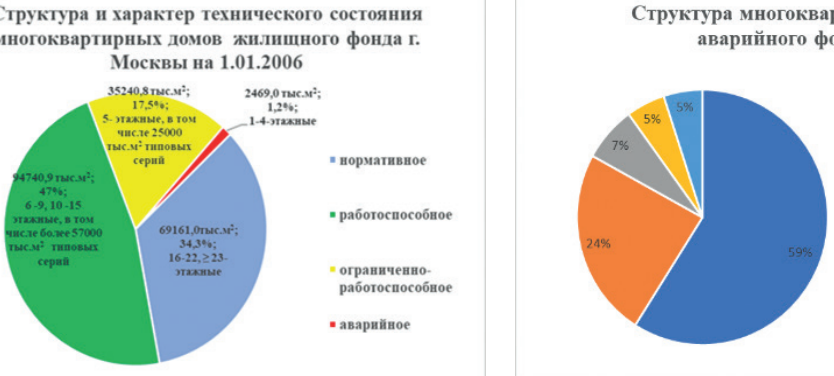

тных домов

(1)

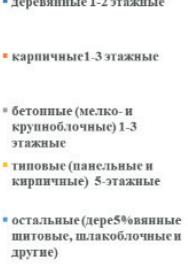

Структура и характер технического состояния многоквартирных ломов жилишного фонда

PФ

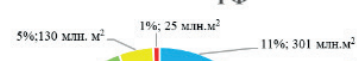

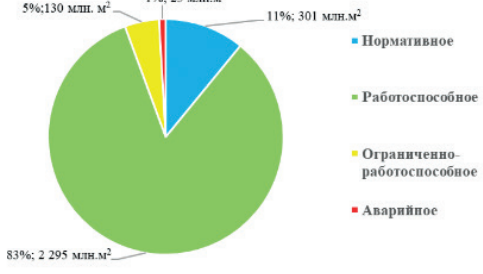

\begin{tabular}{|c|c|c|}
\hline Asapristoe & 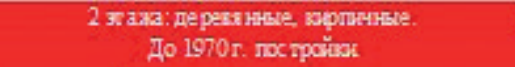 & 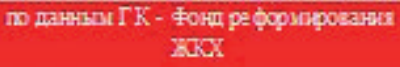 \\
\hline 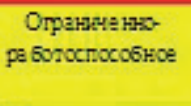 & 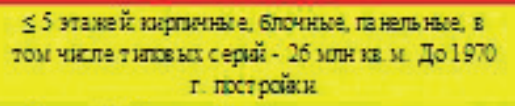 & 3kCre prias olerxa \\
\hline Pa gosoc rocoshoe & 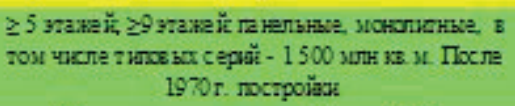 & 3WCRE prHa 8 OIFrxa \\
\hline Hogura тumHoe & 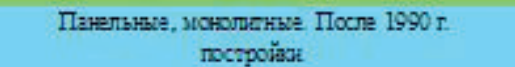 & 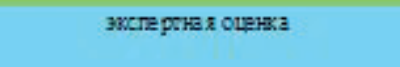 \\
\hline
\end{tabular}

Pис. 3. Структура жилого фонда РФ. Схема авторов статьи 
ектов всё же должна совершенствоваться и развиваться на основе полученных новых знаний, развития техники для всех этапов жизненного цикла зданий и сооружений.

В общем случае, как показывает опыт, безопасность здания или сооружения в процессе эксплуатации с точки зрения механической безопасности и безопасности при опасных природных процессах и явлениях и техногенных воздействиях обеспечивается, прежде всего:

- качеством проекта (в том числе изысканий) и квалификацией его разработчиков;

- качеством используемых строительных материалов, технологий строительства, монтажа, наладки;

- предъявлением в проектной документации требований к способам проведения мероприятий по техническому обслуживанию, при проведении которых отсутствует угроза нарушения безопасности строительных конструкций, сетей и систем инженерно-технического обеспечения или недопустимого ухудшения параметров среды обитания людей;

Таблица 2. Средние значения коэффициентов использования несущей способности конструкций типовых пятиэтажных жилых домов

\begin{tabular}{|c|c|c|c|}
\hline \multirow{2}{*}{ Несущая конструкция } & \multicolumn{3}{|c|}{ Серии зданий } \\
\cline { 2 - 4 } & $1-510$ & $1-511$ & $1-515$ \\
\cline { 2 - 4 } & \multicolumn{3}{|c|}{$\begin{array}{c}\text { Коэффициент использования } \\
\text { несущей способности }\end{array}$} \\
\hline $\begin{array}{c}\text { Простенок наружной } \\
\text { стены }\end{array}$ & 0,49 & 0,97 & 0,35 \\
\hline Внутренняя стена & 0,23 & 0,91 & 0,25 \\
\hline $\begin{array}{c}\text { Горизонтальный стык } \\
\text { внутренней стены }\end{array}$ & 0,47 & - & - \\
\hline То же, наружной стены & - & - & 0,18 \\
\hline
\end{tabular}

Примечание: Коэффициент использования несущей способности - отношение действующей эксплуатационной нагрузки к предельно допустимой нагрузке для реальной конструкции

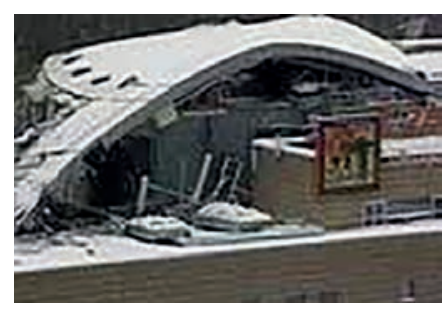

a)

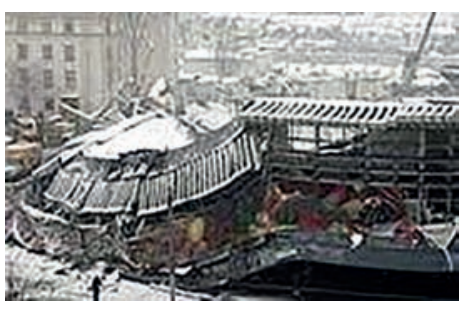

б)

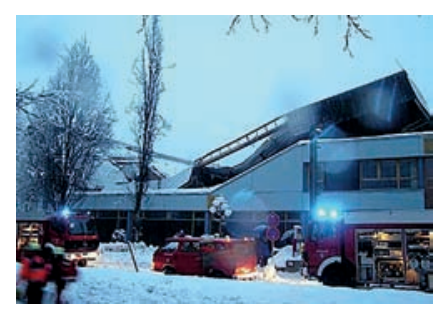

B)
- приведением в проектной документации требований к минимальной периодичности осуществления проверок, осмотров и освидетельствований состояния строительных конструкций, основания, сетей и систем обеспечения здания

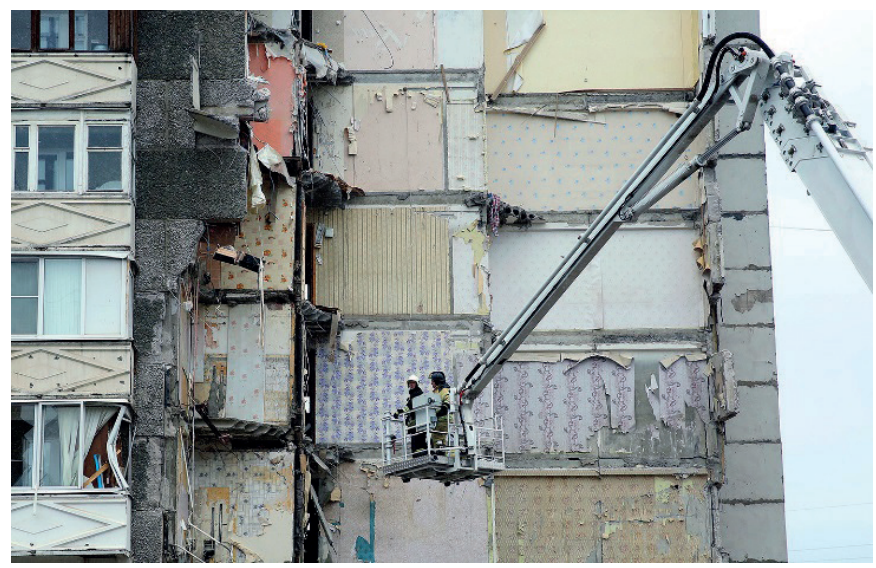

a)

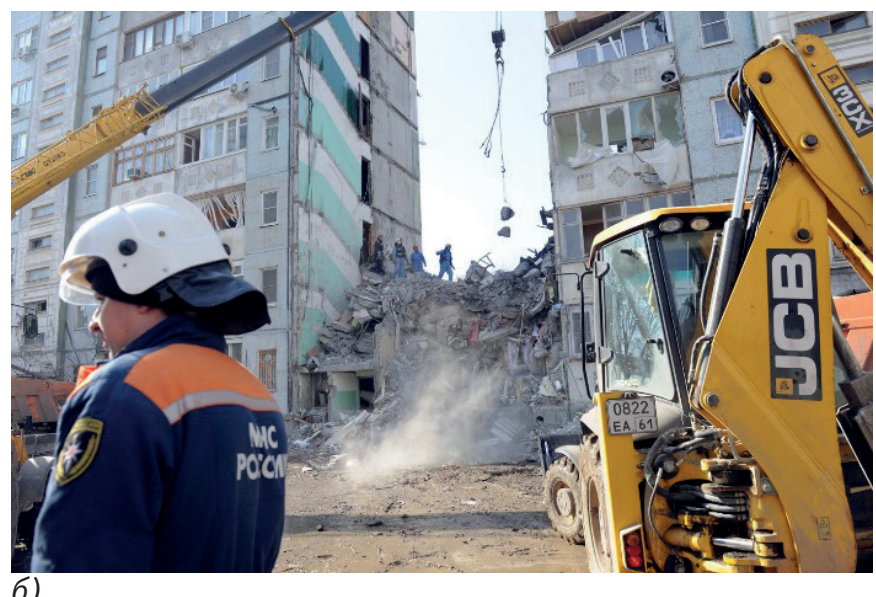

Pис. 4. Последствия взрывов бытового газа в многоэтажных домах, приведших к прогрессирующему обрушению секций зданий (источник: https://life.ru/p/1341260): a) 9 ноября 2017 года. Ижевск; б) 27 февраля 2012 года. Астрахань

Рис. 5 Примеры обрушения покрытий (фото из открытых источников сети Интернет): а) разрушение покрытия купола здания «Трансвааль-парк» (причина - неправомерные проектные решения в сочетании с низким качеством строительных работ и отсутствием надзора за их выполнением). Москва, 2004 год; б) обрушение крыши Басманного рынка (причина-проектные ошибки и неудовлетворительная техническая эксплуатация, местами утеплитель кровли находился в переувлажнённом состоянии, некоторые элементы несущих конструкций оболочки имели коррозийный износ до 50\%) Москва. 2006 год; в) обрушение крыши закрытого катка (причина - ошибки при строительстве, оседание конденсата на опорных балках и скопление снега на крыше здания). Город Бад-Райхенхаль, Германия. 2006 год; г) обрушение части бетонной крыши одного из терминалов в аэропорте Руасси-Шарль де Голль (причина - ошибки при проектировании и строительстве конструкций). Париж, Франция. 2005 год 
или сооружения, к необходимости проведения мониторинга компонентов окружающей среды, состояния основания, строительных конструкций и инженерных систем в процессе эксплуатации здания или сооружения;

- приведением в проектной документации сведений для пользователей и эксплуатационных служб о значениях важнейших эксплуатационных нагрузок на строительные конструкции, инженерные сети и системы обеспечения, которые недопустимо превышать в процессе эксплуатации здания или сооружения; о размещении скрытой электрической проводки, трубопроводов и иныхустройств, повреждение которых может привести к причинению вреда жизни и здоровью людей, имуществу физических или юридических лиц, государственному или муниципальному имуществу, окружающей среде, жизни и здоровью животных и растений;

- реальных данных о сроке эксплуатации здания или сооружения и их частей в соответствии с требованиями ГОСТ 27751, таблица 1 [19].

В соответствии с [14] безопасность здания или сооружения в процессе эксплуатации должна обеспечиваться посредством технического обслуживания, периодических осмотров и контрольных проверок и (или) мониторинга состояния, а также посредством текущих ремонтов здания или сооружения с тем, чтобы параметры и другие характеристики строительных конструкций и систем инженерно-технического обеспечения в процессе эксплуатации здания или сооружения соответствовали требованиям проектной документации, для чего контрольными органами должна осуществляется регулярная оценка соответствия зданий и сооружений в период эксплуатации.

В настоящее время такая процедура реализуется в соответствии с разработанным и утверждённым межгосударственным стандартом ГОСТ 31937-2011 [18], а для сейсмических районов страны - в соответствии с СП 442.1325800.2019 [20]. Эти нормативные документы регламентируют требования к работам и их

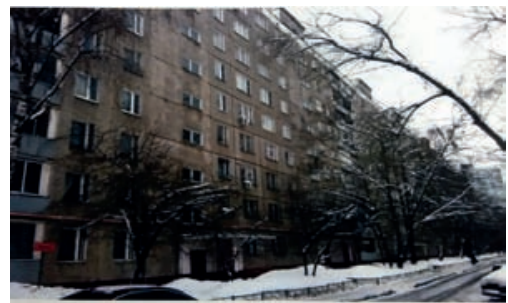

a)

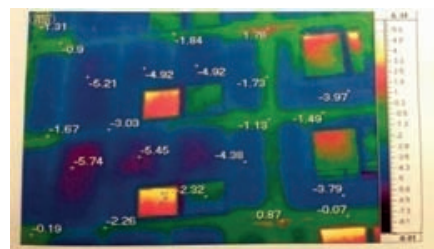

B)

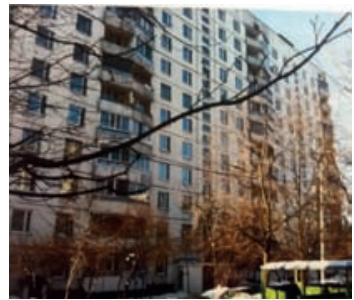

б)

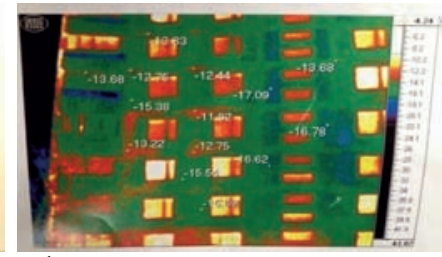

2)
Рис. 6. Результаты (источник: [22]) теплотехнического обследования жилых домов типовых серий: а) общий вид фасада серии II-18; б) общий вид фасада серии II-57; в, г) термограммы наружных стен (цифры - температура наружной поверхности в точке, отмеченной «+») (источник: [9]) составу по получению информации, необходимой для контроля и повышения степени механической безопасности зданий и сооружений, в том числе высотных и большепролётных, зданий и сооружений для контроля состояния несущих конструкций и предотвращения катастроф, связанных с их обрушением.

В этом межгосударственном стандарте введены категории технического состояния, под которыми понимается степень эксплуатационной пригодности несущей строительной конструкции или здания и сооружения в целом, а также грунтов их основания, установленная в зависимости от доли снижения несущей способности и эксплуатационных характеристик. Установлены четыре категории технического состояния здания или сооружения: нормативное, работоспособное, ограниченно-работоспособное, аварийное.

Для конструкций, зданий (сооружений), включая грунтовое основание, находящихся в нормативном техническом состоянии и работоспособном состоянии, эксплуатация при фактических нагрузках и воздействиях возможна без ограничений. Это особенно важно для части массовых типов крупнопанельных (типа «трёхстенка») и панельно-блочных пятиэтажек, срок эксплуатации которыхуже превысил расчётные 50 лет по таблице 1 п. 3 ГОСТ 27751-2014 [19], но они по результатам оценки находятся в работоспособном состоянии).

При этом важно отметить, что по энергоэффективности, как показали результаты теплотехнического обследования жилых домов подобных типовых серий в Москве, эти дома не отвечают современным требованиям безопасности (рис. 6).

Теплотехнические характеристики этих домов в зависимости от серий и их модификаций за время 30-летней эксплуатации снизились более чем на $45 \%$, что почти в два раза ниже современных нормативных требований (табл. 3) [9].

Таким образом, основными мероприятиями при модернизации жилых домов типовых серий, находящихся в нормативном или работоспособном состоянии, при эксплуатации являются не усиление конструкций, а дополнительное утепление наружных стен, замена оконных блоков на стеклопакеты, остекление балконов, установка автоматизированных тепловых узлов и другие энергосберегающие мероприятия. Что касается стадии их утилизации, то говорить об экологической безопасности при использовании разрушающих способов с применением гидроножниц и гидромолотов, не приходится, поскольку «умный» демонтаж панелей этих домов практически невозможен, их узлы не отвечают требованиям ремонтопригодности.

При ограниченно-работоспособном состоянии конструкций, зданий (сооружений), включая грунтовое основание, контролируют их состояние, проводят мероприятия по восстановлению или усилению конструкций и (или) грунтового основания и последующий мониторинг технического состояния (при необходимости).

Эксплуатация зданий (сооружений) при аварийном состоянии конструкций, включая грунтовое основание, не допускается. Устанавливается обязательный режим мони- 
торинга для отслеживания степени и скорости изменения технического состояния объекта и принятия в случае необходимости экстренных мер по предотвращению его обрушения или опрокидывания.

Категории технического состояния зданий и сооружений очевидно связаны с вопросами оценки соответствия зданий и сооружений, особенно при эксплуатации. В настоящее время вопросы процедур подтверждения соответствия зданий и сооружений, их конструкций и систем практически не отражены в нормативно-технической документации, посвящённой процессам их эксплуатации. Они отражены лишь в нормативно-технической документации, разработанной на основе еврокодов, например, ГОСТ Р 57364-2016/EN 15129:2010 [21].

Для систематизации и дальнейшего развития нормативно-технической базы по обеспечению механической безопасности зданий и сооружений на этапе их эксплуатации с учётом разработанных нормативных документов предлагается следующая структура нормативно-технических документов:

1 - нормативно-технические документы по обеспечению безопасности существующей застройки населённых пунктов (территорий), в том числе на особых территориях (сейсмических, с вечномёрзлыми грунтами, подрабатываемых, подтопляемых, цунамиопасных и др.);

2 - нормативно-технические документы по обеспечению безопасности жилых, социально-культурных строительных объектов в период их эксплуатации, в том числе уникальных зданий и сооружений;
3 - нормативно-технические документы по обеспечению безопасности промышленных зданий и сооружений в период их эксплуатации, в том числе уникальных зданий и сооружений, линейных объектов;

4 - нормативно-технические документы по обеспечению безопасности особо опасных и технически сложных объектов в период их эксплуатации;

5 - нормативно-технические документы по обеспечению безопасности на стадии сноса и реконструкции существующей застройки.

По первому направлению предложенной структуры нормативно-технических документов необходимо разработать ряд нормативных документов, касающихся: зонирования как территории страны в целом, так и территорий отдельных субъектов Федерации и (или) населённых пунктов с целью получения информации, необходимой для повышения безопасности эксплуатируемой застройки; разработки систем мониторинга технического состояния существующей застройки населённых пунктов с целью своевременного выявления зданий и сооружений, требующих первоочередного выполнения превентивных мероприятий для обеспечения их эксплуатационной безопасности; систем прогноза последствий: длительной эксплуатации существующей застройки населённых пунктов (например, накопления ветхого и аварийного жилья); сильных землетрясений для населённых пунктов сейсмических территорий страны; оттаивания вечномёрзлых грунтов для населённых пунктов арктической зоны страны и др.

Таблица 3. Значения «остаточного теплотехнического ресурса» ограждающих конструкций зданий различных типовых серий

\begin{tabular}{|l|c|c|}
\hline \multicolumn{1}{|c|}{ Наименование серий } & & Остаточный теплотехнический ресурс \\
\multicolumn{1}{|c|}{ их модификаций } & Конструкции наружной стены \\
$R_{\text {m }}$ \\
$R_{\mathrm{n}}$
\end{tabular}


Так, например, для сейсмических территорий зонирование страны отражается в настоящее время на картах общего сейсмического районирования (ОСР) (и в соответствующих перечнях населённых пунктов [22]), состав, надёжность и методы разработки которых не регламентируются никаким нормативно-техническим документом, в то время как зонирование отдельных субъектов Федерации и населённых пунктов осуществляется на основе детального сейсмического районирования (ДСР) в соответствии с [23] и [24]. Зонирование территории населённых пунктов осуществляется на основе сейсмомикрорайонирования (СМР) в соответствии с [25].

Для мониторинга существующей застройки населённых пунктов сейсмических территорий и разработки соответствующих информационных систем особенно важна цифровизация, однако состав таких информационных систем для населённых пунктов, субъектов Федерации и страны в целом не регламентируется каким-либо нормативно-техническим документом. Предложения, которые могли бы стать основой такого нормативного документа, представлены, например, в [12]. Прогноз последствий сильных землетрясений для населённых пунктов, расположенных в сейсмических районах страны, является основой безопасности проживания населения в этих населённых пунктах, так как даёт информацию для осуществления превентивных мероприятий по усилению зданий и сооружений, обладающих недостаточной сейсмостойкостью. Нормативно-технического документа, регламентирующего такой прогноз, в настоящее время нет. За основу такого нормативного документа (СП «Территории сейсмические. Правила представления прогноза последствий землетрясений») могли бы быть взяты, например, предложения из [13]. Эти предложения базируются на действующем нормативно-техническом документе [20].

По второму и третьему направлениям дальнейшие перспективы связаны с разработкой и внедрением цифровых методов и систем повышения эффективности эксплуатации, включая технологии информационного моделирования и автоматизированного мониторинга технического состояния

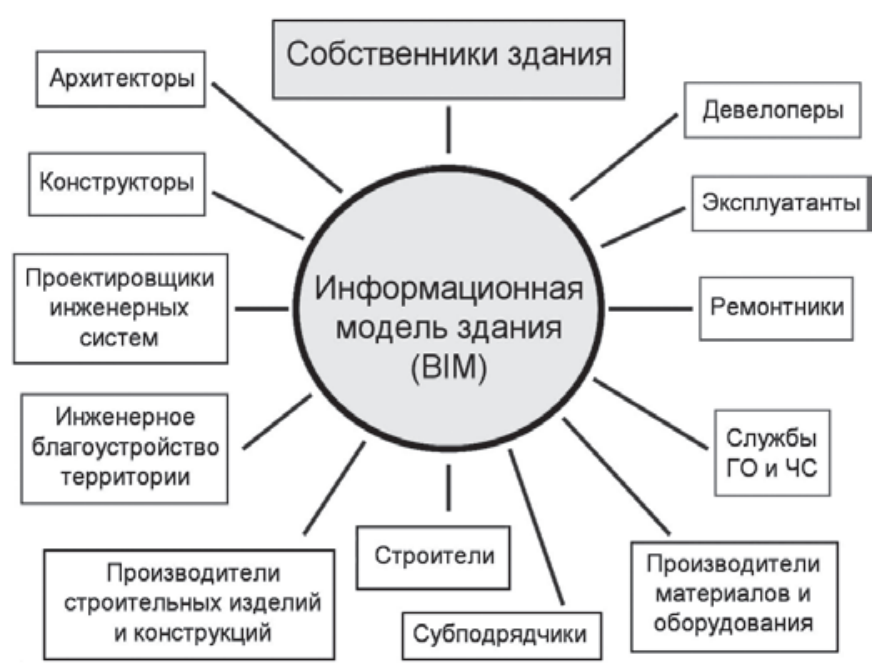

Рис. 7. Использование цифровой модели здания на стадиях жизненного цикла объекта. Схема авторов статьи
[10] (рис. 7). За рубежом, например, цифровые модели зданий широко используются при их эксплуатации.

Например, в Словении, где условия эксплуатации нормируются только для нежилых объектов, разработана и внедрена при строительстве здания бизнес-складов компании Халдер в городе Хоче собственная цифровая динамическая модель эксплуатации [11].

Алгоритм разработки состоял из нескольких этапов. Сначала в цифровом виде была составлена спецификация элементов для эксплуатации. После этого для каждого элемента были определены сроки службы и мероприятия по обслуживанию, а также общий прогнозный срок службы здания - 60 лет. Затем рассчитали сроки и стоимость этих работ путём модернизации 5D-модели с помощью модуля, связанного с 3D-BIM-моделями каждого элемента. Результатом анализа сроков стал график работ по обслуживанию. На базе полученных данных по стоимости и срокам была разработана модель текущего обслуживания и капитального ремонта здания на весь расчётный срок службы.

В России по этому вопросу разработаны СП 333.1325800.2017 [26], проект стандарта «Информационное моделирование в строительстве. Требования к формированию информационных моделей объектов капитального строительства для эксплуатации многоквартирных домов» и ГОСТ Р 57311-2016 [27].

Положения этих нормативных документов содержат базовые требования к информационным моделям объектов массового строительства и их разработке на различных стадиях жизненного цикла и направлены на повышение обоснованности и качества проектных решений, повышение уровня безопасности при строительстве и эксплуатации. Общие подходы к формированию информационных моделей обеспечивают простоту их использования и повышают эффективность процесса информационного моделирования. Современные возможности компьютерного моделирования позволяют прогнозировать, например, физические процессы, протекающие в несущих конструкциях, и более точно рассчитывать срок их службы [10]. На основе компьютерного моделирования можно прогнозировать и сроки управляющих воздействий (профилактических и текущих ремонтов).

По второму и третьему направлениям предложенной структуры нормативно-технических документов ведутся работы. Так, разработаны общие для них документы [18; 28; 29]. По второму направлению в настоящее время действуют своды правил [30-36], по третьему направлению - [37-44].

По второму, третьему и четвёртому направлениям в настоящее время действуют межгосударственные стандарты [18, $45,46]$. При подготовке нормативно-технических документов для особо опасных и технически сложных объектов в период их эксплуатации необходимо учитывать [47].

По пятому направлению - стадии утилизации объекта стройной системы пока нет, действует лишь СП 325.1325800.2017 [48]. На этой стадии при разработке нормативной базы необходим учёт современных требований экономики полного цикла (так называемой циркулярной экономики). Рекомендуется для её разработки использовать представленные ниже положения европейского документа [49]. 
При проектировании конструкций по жизненному циклу необходимо предусматривать возможность в будущем их усиления, демонтажа, изменения функционального предназначения. Отдельно следует рассматривать сооружения с большими пролётами, которые при реконструкции проще приспособить для новых функций.

В прошлом такие задачи перед проектировщиками не ставились. Однако возросшие объёмы реновации прежней застройки вызвали необходимость разработки соответствующего оборудования для разборки и разрушения устаревшего фонда.

Конструкции следует считать исчерпавшими свой эксплуатационный ресурс в следующих случаях:

- дальнейшая их эксплуатация не отвечает требованиям безопасности;

- конструкция не в состоянии выполнять свои изначальные функции;

- её реновация и приспособление к новым эксплуатационным требованиям нецелесообразны по экономическим соображениям.

Процесс демонтажа существующих конструкций требует тщательной подготовки. Техническое задание на демонтаж должен предусматривать повторное использование или утилизацию образовавшихся отходов. Конструкция до начала демонтажа должна пройти обследование для оценки её несущей способности, устойчивости на различных этапах демонтажа.

Должны быть приняты меры по снижению негативного воздействия процесса демонтажа на окружающую среду в части уровня шума, пыли вибрации и т.д.

При частичном демонтаже должны быть приняты меры по обеспечению устойчивости неповреждаемой (остающейся) части конструкции.

Техническое задание должно предусматривать возможность повторного использования образующихся отходов. При этом следует иметь в виду, что долговечность строительных материалов повторного использования может быть ниже, чем новых.

При подготовке плана демонтажа того или иного сооружения следует принимать во внимание класс сооружения по ответственности согласно классификации, указанной в таблице 2 ГоСт 27751, технические характеристики, условия стройплощадки, ограничения по времени, условия размещения образующихся отходов, требования по охране окружающей среды. Безопасность труда для сооружений классов по ответственности 2-го и 3-го должна быть предусмотрена в детальном плане демонтажных работ. Для каркасных систем следует учитывать особо наличие диафрагм или ядер жёсткости. Специфика смешанных систем может быть определяющей для выбора технологии демонтажа. Соответствующие меры должны быть приняты для обеспечения устойчивости остающейся части здания по мере его разборки. Следует оценивать несущую способность части конструкций для размещения механизмов, используемых для её демонтажа. Особого анализа требует применение взрывной технологии для разрушения конструкций.
При планировании размещения образующихся отходов должны быть оценены объёмы образующихся отходов, возможность их использования непосредственно на месте или близлежащих площадях. Следует принять меры по обезвреживанию отдельных компонентов демонтируемого здания.

План по разборке объекта должен включать перечень демонтажных механизмов и транспортных единиц, необходимых для производства работ, технологические приёмы обращения с вредными выбросами, указания на размещения в отвалах или повторное использование образующихся отходов, а также меры по технике безопасности и охране окружающей среды.

Для финансирования работ по утилизации необходимо также разработать для смет строительства дифференцированные расценки утилизационного сбора в зависимости от типа объекта, его конструктивной схемы и с учётом предложений Ассоциации демонтажных организаций России.

\section{***}

Таким образом, на основе проведённого анализа можно утверждать, что в настоящее время существующая нормативная база по обеспечению требований Технического регламента о безопасности зданий и сооружений не в полной мере охватывает стадии эксплуатации и утилизации строительных объектов. Для улучшения ситуации:

1) необходима разработка нормативно-технического документа, подобного СНиПу 10-01 «Система нормативных документов в строительстве. Основные положения»;

2) предложена структура развития нормативно-технической базы в области комплексной безопасности, предусматривающая дальнейшее наполнение нормативами стадии эксплуатации и утилизации объектов;

3) для реализации всей представленной авторами структуры нормативно-технических документов и сучётом вышеописанных уже реализуемых направлений необходимы научно-исследовательские работы по следующим основным направлениям:

- изучение долговечности строительных материалов, конструкций и изделий;

- изучение живучести строительных объектов и мероприятий по её восстановлению в аварийных ситуациях;

- развитие современных методов диагностики и автоматизированного мониторинга на основе цифровых технологий;

- цифровое моделирование и разработка информационных систем;

- разработка нормативов сноса и утилизации продуктов разборки объектов, в том числе из местных материалов, применительно к региональным нормам комплексного развития территорий.

\section{Лumepamypa}

1. Развитие нормативно-правовой базы для реализации национального проекта «Жильё и городская среда» / А.Н. Дмитриев, В.В. Гурьев, В.М. Дорофеев, С.М. Яхкинд // Актуальные проблемы в инвестиционно-строительной сфере и при- 
родопользовании : Сборник материалов научно-практической конференции. - М. : РЭУ им. Г.В. Плеханова, 2019. - С. 167-172.

2. Системы сертификации по стандартам «зелёного строительства» в мире и в России / Б.Н. Порфирьев, А.Н. Дмитриев, И.Л. Владимирова, А.А. Цыганкова // Стандарты и качество. - 2015. - № 10. - С. 26-31.

3. Об экономических проблемах и механизмах реновации и реконструкции пятиэтажной застройки / Дмитриев А.Н., Гурьев В.В., Дорофеев В.М. [и др.] // Экономика строительства. - 2018. - № 1 (49). - С. 3-17.

4. Травуш, В.И. 0 параметрической (performance based) модели нормирования и требованиях ГОСТ 27751-2014 «Надёжность строительных конструкций и оснований. Основные положения» / В.И. Травуш, Ю.С. Волков // БСТ: Бюллетень строительной техники. - 2018. - № 2 (1002). - С. 36-38.

5. Травуш, В.И. 0 противоречиях обязательности и добровольности применения строительных норм / В.И. Травуш, Ю.С. Волков // БСТ: Бюллетень строительной техники. - 2018. № 3 - (1003). - С. 18-20.

6. 0 нормировании аварийного жилищного фонда / 0.С. Рурин, Н.Г. Келасьев, В.В. Гранёв [и др.] // Промышленное и гражданское строительство. - 2020. - № 9. - С. 73-78.

7. Гурьев, В.В. Оценка параметров остаточного ресурса зданий массовой застройки первого периода индустриального домостроения / В.В. Гурьев, В.М. Дорофеев, М.С. Дузинкевич // Промышленное и гражданское строительство. - 2006. - № 4. - С. 24-25.

8. Дорофеев, В.М. 0 результатах комплексного обследования жилых зданий второго периода индустриального домостроения / В.М. Дорофеев, М.С. Дузинкевич, Д.А. Лысов // Промышленное и гражданское строительство. - 2008. - № 12. - С. 27-31.

9. Гохберг, Ю.Ц. Энергоэффективность наружных ограждающих конструкций жилых зданий второго периода индустриального домостроения при капитальном ремонте в г. Москве / Ю.Ц. Гохберг, М.В. Светлаков, Е.В. Хаимова-Малькова // Academia. Архитектура и строительство. - 2010. - № 3. - 450-455.

10. Цифровые методы в инновационном управлении инвестиционно-строительными проектами : Монография / Под ред. д.э.н. проф. И.Д. Владимировой. - М. : РЭУ им. Г.В. Плеханова, 2020. -448 c.

11. Zoran Pučko, DraženVincek, Andrej Štrukelj, Nataša Šuman. Application of 6D Building Information Model (6D BIM) for Business-storage Building in Slovenia/IOP Conf. Series: Materials Science and Engineering 245 (2017).

12. Гурьев, В.В. 0 проблемах нормирования безопасности застроенных территорий в сейсмических районах / В.В. Гурьев, В.М. Дорофеев // Фундаментальные, поисковые и прикладные исследования РААСН по научному обеспечению развития архитектуры, градостроительства и строительной отрасли Российской Федерации в 2019 году : Сб. науч. тр. PAACH. - М. : АСВ, 2020. - С. 157-178.

13. Дорофеев, В.М. Прогноз последствий сильных землетрясений / В.М. Дорофеев, А.С. Денисов // Природные и техногенные риски. Безопасность сооружений. - 2019. -№ 1. - С. 28-31.

\section{References}

1. Dmitriev A.N., Gur'ev V.V., Dorofeev V.M., Yakhkind S.M. Razvitie normativno-pravovoi bazy dlya realizatsii natsional'nogo proekta Zhil'e i gorodskaya sreda [Development of the regulatory andlegal framework for the implementation of the national project Housing and urban environment]. In: Aktual'nye problemy $v$ investitsionno-stroitel'noi sfere $i$ prirodopol'zovanii : Sbornik materialov nauchno-prakticheskoi konferentsii [Actual problems in the investment and construction sector and environmental management: Collection of materials of the scientific and practical conference]. Moscow, REU im. G.V.Plekhanova Publ., 2019. (In Russ., abstr. in Engl.)

2. Porfir'ev B.N., Dmitriev A.N., Vladimirova I.L., Tsygankova A.A. Sistemy sertifikatsii po standartam «zelenogo stroitel'stva» v mire i v Rossii [Certification systems for "green building" standards in the world and in Russia]. In: Standarty $i$ kachestvo [Standards and Quality], 2015, no. 10, pp. 26-31. (In Russ.)

3. Dmitriev A.N., Gur'ev V.V., Dorofeev V.M., Lepeshkina E.A., Pankratov E.P. Ob ekonomicheskikh problemakh i mekhanizmakh renovatsii i rekonstruktsii pyatietazhnoi zastroiki [On economic problems and mechanisms of renovation and reconstruction of a fivestorey building]. In: Ekonomika stroitel'stva [Economics of Construction], 2018, no. 1 (49), pp. 3-17. (In Russ., abstr. in Engl.)

4. Travush V.I., Volkov Yu.S. 0 parametricheskoi (performance based) modeli normirovaniya i trebovaniyakh GOST 27751-2014 "Nadezhnost' stroitel'nykh konstruktsii i osnovanii. Osnovnye polozheniya" [0n the performance based model of regulation and the requirements of GOST 27751-2014 "Reliability of building structures and foundations. Basic provisions]. In: BST: Byulleten' stroitel'noi tekhniki [BST. Construction Technique Bulletin], 2018, no. 2 (1002), pp. 36-38. (In Russ., abstr. in Engl.)

5. Travush V.I., Volkov Yu.S 0 protivorechiyakh obyazatel'nosti i dobrovol'nosti primeneniya stroitel'nykh norm [On the contradictions of obligation and voluntariness of the application of building codes]. In: BST: Byulleten' stroitel'noi tekhniki [BST. Construction Technique Bulletin], 2018, no. 3 (1003), pp. 18-20. (In Russ., abstr. in Engl.)

6. Rurin 0.S., Kelas'ev N.G., Granev V.V., Gur'ev V.V., Denisov A.S. 0 normirovanii avariinogo zhilishchnogo fonda [0n rationing of emergency housing stock]. In: Promyshlennoe $i$ grazhdanskoe stroitel'stvo [Industrial and Civil Engineering], 2020, no. 9, pp. 73-78. (In Russ., abstr. in Engl.)

7. Gur'ev V.V., Dorofeev V.M., Duzinkevich M.S. Otsenka parametrov ostatochnogo resursa zdanii massovoi zastroiki pervogo perioda industrial'nogo domostroeniya [Estimation of the parameters of the residual resource of buildings of mass development of the first period of industrial housing construction]. In: Promyshlennoe i grazhdanskoe stroitel'stvo [Industrial and Civil Engineering], 2006, no. 4, pp. 24-25. (In Russ.)

8. Dorofeev V.M., Duzinkevich M.S., Lysov D.A. 0 rezul'tatakh kompleksnogo obsledovaniya zhilykh zdanii vtorogo perioda industrial'nogo domostroeniya [0n the results of a comprehensive survey of residential buildings of the second period of industrial 
housing construction]. In: Promyshlennoe i grazhdanskoe stroitel'stvo [Industrial and Civil Engineering], 2008, no. 12, pp. 26-29. (In Russ., abstr. in Engl.)

9. Gokhberg Yu.Ts., Svetlakov M.V., Khaimova-Mal'kova E.V. Ener-goeffektivnost' naruzhnykh ograzhdayushchikh konstruktsii zhilykh zdanii vto-rogo perioda industrial'nogo domostroeniya pri kapital'nom remonte $v \mathrm{~g}$. Moskve [Energy efficiency of external enclosing structures of residential buildings of the second period of industrial housing construction during major repairs in Moscow]. In: Academia. Arkhitektura i stroitel'stvo [Academia. Architecture and construction], 2010, no. 3, pp. 450-455. (In Russ., abstr. in Engl.)

10. Vladimirova I.D. (ed). Tsifrovye metody v innovatsionnom upravlenii investitsionno-stroitel'nymi proektami [Digital methods in innovative management of investment and construction projects], Monograph. Moscow, REU im. G.V. Plekhanova Publ., 2020, 448 p. (In Russ.)

11. Zoran Pučko, DraženVincek, Andrej Štrukelj, Nataša Šuman. Appli-cation of 6D Building Information Model (6D BIM) for Business-storage Building in Slovenia. In: IOP Conf. Series: Materials Science and Engineering 245 (2017). (In Engl.)

12. Gur'ev V.V., Dorofeev V.M. 0 problemakh normirovaniya bezopasnosti zastroennykh territorii $v$ seismicheskikh raionakh [0n the problems of rationing the safety of built-up areas in seismic regions]. In: Fundamental'nye, poiskovye i prikladnye issledovaniya RAASN po nauchnomu obespecheniyu razvitiya arkhitektury, gradostroitel'stva i stroitel'noi otrasli Rossiiskoi Federatsii v 2019 godu [Fundamental, prospecting and applied research of the RAASN on scientific support for the development of architecture, urban planning and the construction industry of the Russian Federation in 2019]: Collection of scientific papers of RAACS. Moscow, ASV Publ., 2020, pp. 157-178. (In Russ., abstr. in Engl.)

13. Dorofeev V.M., Denisov A.S. Prognoz posledstvii sil'nykh zemletryasenii [Forecast of the consequences of strong earthquakes]. In: Prirodnye i tekhnogennye riski. Bezopasnost' sooruzhenii [Natural and technogenic risks. Safety of structures], 2019, no. 1, pp. 28-31. (In Russ., abstr. in Engl.)

Перечень нормативно-правовых актов и источников

14. Федеральный закон Российской Федерации № 384-Ф3 от 30.12.2009 «Технический регламент о безопасности зданий и сооружений».

15. ГОСТР 54964-2012. «0ценка соответствия. Экологические требования к объектам недвижимости».

16. Федеральный закон Российской Федерации № 184-Ф3 от 27.12.2002 «0 техническом регулировании».

17. СП 255.1325800.2016 Здания и сооружения. Правила эксплуатации. Основные положения (с изменениями № 1, № 2).

18. ГОСТ 31937-2011 Здания и сооружения. Правила обследования и мониторинга технического состояния.

19. ГОСТ 27751-2014. Надёжность строительных конструкций и оснований. Основные положения.

20. СП 442.1325800.2019. «Здания и сооружения в сейсмических районах. Оценка класса сейсмостойкости».
21. ГОСТ Р 57364-2016/EN 15129:2010. «Устройства антисейсмические. Правила проектирования» (EN 15129: Antiseismicdevices, IDT).

22. СП 14.13330.2018 Строительство в сейсмических районах. Актуализированная редакция СНиП II-7-81* (с Изменением №1).

23. СП 286.1325800.2016 0бъекты строительные повышенной ответственности. Правила детального сейсмического районирования.

24. СП 408.1325800.2018. Детальное сейсмическое районирование и сейсмомикрорайонирование для территориального планирования.

25. СП 283.1325800.2016. Объекты строительные повышенной ответственности. Правила сейсмического микрорайонирования.

26. СП 333.1325800.2017. Информационное моделирование в строительстве. Правила формирования информационной модели объектов на различных стадиях жизненного цикла.

27. ГОСТ Р 57311-2016. Моделирование информационное в строительстве. Требования к эксплуатационной документации объектов завершённого строительства.

28. СП 304.1325800.2017. Конструкции большепролётных зданий и сооружений. Правила эксплуатации.

29. СП 432.1325800.2019. Покрытия огнезащитные. Мониторинг технического состояния.

30. СП 306.1325800.2017 Многофункциональные торговые комплексы. Правила эксплуатации.

31. СП 319.1325800.2017. Здания и помещения медицинских организаций. Правила эксплуатации.

32. СП 368.1325800.2017. Здания жилые. Правила проектирования капитального ремонта.

33. СП 372.1325800.2018. Здания жилые многоквартирные. Правила эксплуатации.

34. СП 394.1325800.2018. Здания и комплексы высотные. Правила эксплуатации.

35. СП 418.1325800.2018. Здания и сооружения спортивные. Правила эксплуатации.

36. СП 454.1325800.2019. Здания жилые многоквартирные. Правила оценки аварийного и ограниченно-работоспособного технического состояния.

37. СП 307.1325800.2017 Здания и помещения для хранения и переработки сельскохозяйственной продукции. Правила эксплуатации.

38. СП 312.1325800.2017 Дороги внутрихозяйственные. Правила эксплуатации.

39. СП 318.1325800.2017. Дороги лесные. Правила эксплуатации.

40. СП 324.1325800.2017. Здания многоэтажные промышленных предприятий. Правила эксплуатации.

41. СП 343.1325800.2017. Сооружения промышленных предприятий. Правила эксплуатации.

42. СП 374.1325800.2018. Здания и помещения животноводческие, птицеводческие и звероводческие. Правила эксплуатации. 
43. СП 377.1325800.2017. Сооружения портовые. Правила эксплуатации.

44. СП 469.1325800.2019. Сооружения животноводческих, птицеводческих и звероводческих предприятий. Правила эксплуатации.

45. ГОСТ 32019-2012. Мониторинг технического состояния уникальных зданий и сооружений. Правила проектирования и установки стационарных систем (станций) мониторинга.

46. ГОСТ 34081-2017. Здания и сооружения. Определение параметров основного тона собственных колебаний.
47. Федеральный закон Российской Федерации № 116-Ф3 от 21.07.1997 «0 промышленной безопасности опасных производственных объектов.

48. СП 325.1325800.2017. Здания и сооружения. Правила производства работ при демонтаже и утилизации.

49. International Federation for Structural Concrete - fib Model Code for Concrete Structures 2010, Lausanne, Switzerland.

Травуш Владимир Ильич (Москва). Доктор технических наук, профессор, академик РААСН (127025, Москва, Новый Арбат, 19. РАACH). Вице-президент РАAСН; главный конструктор 3 А0 «Горпроект» (105064, Москва, Нижний Сусальный переулок, д.5, стр. 5A. Горпроект). Эл. почта: travush@mail.ru.

Гурьев Владимир Владимирович (Москва). Доктор технических наук, профессор, советник РААСН. Научный руководитель ФАУ «Федеральный центр нормирования, стандартизации и технической оценки соответствия в строительстве» (101000, Москва, Фуркасовский переулок, д.6. ФАУ «ФЦС»). Эл.почта: guryev@faufcc.ru.

Дмитриев Александр Николаевич (Москва). Доктор технических наук, профессор. Профессор Базовой кафедры «Управление проектами и программами Capital group» Российского экономического университета им. Г,В. Плеханова (Москва, Стремянный переулок, д.36). Эл. почта: alexander.dmitriev@inbox.ru.

Дорофеев Владимир Михайлович (Москва). Кандидат физико-математических наук, старший научный сотрудник. Главный специалист ФАУ «Федеральный центр нормирования, стандартизации и технической оценки соответствия в строительстве» (101000, Москва, Фуркасовский переулок, д.6. ФАУ «ФЦС»). Эл. почта: vm.dorofeev2015@yandex.ru.

Волков Юрий Сергеевич (Москва). Кандидат технических наук, почётный член РААСН. Учёный секретарь Научно-исследовательского института бетона и железобетона АО НИЦ «Строительство» (109428, Москва, 2-ая институтская, 6. НИИЖБ им А.А.Гвоздева). Эл. почта: volkov@cstroy.ru.

Travush Vladimir I. (Moscow). Doctor of Technical Sciences, Professor, Academician of RAACS (19 Noviy Arbat st., Moscow, 127025. RAACS). Vice-President of RAACS (24 Bolshaya Dmitrovka, build. 1, Moscow, 107031), Chief Structural Engineer of ZA0 "Gorproekt" (5 Nizhny Susalnylane, build. 5A, Moscow, 105064. ZA0 "Gorproekt"). E-mail: travush@raasn.ru

Guriev Vladimir V. (Moscow). Doctor of Technical Sciences, Professor, Advisor of RAACS. Chief Scientific Officer of Federal autonomous institution "Federal centre for regulation, standardization and technical assessment in construction" (Furkasovsky lane, build. 6, Moscow, 101000. FAU "FCC"). E-mail: guryev@faufcc.ru.

Dmitriev Alexander-N. (Moscow). Doctor of Technical Sciences, Professor. Professor of the Basic Department "Project and Program Management of Capital group" of the Plekhanov Russian University of Economics (Moscow, Stremyanny per.) E-mail: alexander. dmitriev@inbox.ru.

Dorofeev Vladimir I. (Moscow). Candidat of Physical and Mathematical Sciences, Senior scientific researcher. Chief Specialist of Federal autonomous institution "Federal centre for regulation, standardization and technical assessment in construction" (Furkasovskylane, build.6, Moscow, 101000. FAU "FCC"). E-mail: vm.dorofeev2015@yandex.ru.

Volkov Yuri S. (Moscow). PhD (Tech), Honorary Member of RAACS. Scientific Secretary of Research Institue on Concrete and RC AO «NITS "Stroitelstvo"», Russian Academy of Archtecture and Building, (6, 2nd instituskaja, Moscow, 109428. NIIZhB named after A.A.Gvozdev). E-mail: volkov@cstroy.ru. 